\title{
The Need for Horizontal Application of Fundamental Rights in India with Reference to State Action Doctrine in the Context of Globalisation
}

\author{
Sanu Rani Paul*
}

\begin{abstract}
A paradigm shift in the role of the state has taken place with the emergence of private and private public participation in the socio welfare sectors of the economy. These private and public entities through their operations are making unreasonable interference in the lives of people thereby violating their fundamental rights. The judiciary has a significant role to play in protecting and upholding the fundamental rights of the citizens under the Constitution of India. But as far as enforcement of fundamental rights against private or non state actors is concerned, our judiciary is constrained in a set of narrow doctrines evolved from time to time. In the present scenario, an innovative and liberal approach in tune with the spirit and fundamental values of the Constitution is the need of the hour. The present study gives an account of the need for enforcement of fundamental rights in India against non state actors through an expansion of the concept of state action.
\end{abstract}

Keywords: Constitution of India; Fundamental Rights; Globalisation; State, State Action Doctrine

* Research Scholar, Department of Studies in Law, University of Mysore, Mysore; sanuranipaul@gmail.com 


\section{Introduction}

The conflict between man and the state is as old as human history. It is primarily because of the dynamic nature of the human society where old values, ideas and forces constantly yield place to the new ones. ${ }^{1}$ The eternal problem faced by statesmen is to strike a balance between individual liberty and social control. ${ }^{2}$ A common device that is adopted by modern democratic states for this purpose is the incorporation of fundamental rights in their constitutions and guaranteeing their inviolability by executive and legislative organs. ${ }^{3}$ The constitutions of free democratic nations are the most powerful devices created by the political societies for preserving and promoting the supreme values which makes the good of attaining dignified human personhood for all, a possible reality. ${ }^{4}$ Ultimately, the relation between individual right and the governmental power depends upon the nature and role of the state. ${ }^{5}$

The concept of statehood has undergone a paradigm shift due to globalisation and so is the relationship between the individual rights and the governmental power. In developing countries, globalisation is leading to shrinking of public space, violation of human rights and commoditisation of citizens ${ }^{6}$ and an upsurge of democratic processes. The traditional model of constitutional rights, based on liberal legalism, is no longer accurate in the current era of 'legal pluralism,' i.e., globalised political power given to both nation states and non state actors, such as multinational

\footnotetext{
${ }^{1}$ M.V. Pylee, Constitutional Government in IndiA 185 (2nd ed. 1968).

225 JOHN STUART MiLL, ON LIBERTY 6 (1909).

${ }^{3}$ PYLEE, supra note 1.

4 DR. P. ISHWARA BHAT, A CRITICAL STUdy OF INTER-RELATIONSHIP AMONG FundAMENTAL RigHTS WITH SPECIAL REFERENCE TO THE CONSTITUTION OF INDIA 1(1993).
}

${ }^{5} \mathrm{Id}$. at 15 .

${ }^{6}$ Ali Farazmand, Globalisation and Public Administration, 59 PUB. ADMIN. REV. (1999). 
corporations.7 Globalisation has brought in a culture of neo liberalisation and in the era of neoliberalism there is a need to revise constitutional rights in the light of global transformations and to rethink the understanding of liabilities of private entities in light of the relative advancement of their public capacity and public authority particularly when their conduct has been found in violation of constitutional rights.

\section{Fundamental Rights under the Constitution of India}

Part III of the Constitution enlists fundamental rights and this chapter is called as the Magna Carta of the Constitution of India. The inclusion of this chapter on fundamental rights is to preserve the basic elementary rights such as right to life, liberty, fundamental freedoms which should be regarded as sacrosanct with least interferences from the people in power. Fundamental rights were incorporated into the Constitution with an idea that a code of social philosophy regulating the conduct of everyone will remind the legislature and executive whenever they begin to encroach rights and also to provide an opportunity for citizens to create public opinion against such measures. ${ }^{8}$

The Constitution preserves the natural rights against state encroachments and constitutes the higher judiciary of the state as the sentinel of the said rights. ${ }^{9}$ The reason is that the freedom fighters in India had learnt from their experience that even a representative assembly of men might be arbitrary and hostile to the cherished rights of men. As Laski wrote: "And Indians believed in the 'federation of minorities' a declaration of rights was as necessary as it had been for the Americans when they first established their federal constitution" ${ }^{10}$

716 GAVin W. ANDERSON, CONSTITUtional Rights AFTER GLOBALiSATION 12 (2005).

8 PYLEE, supra note 1 at 190.

9 D.D. BASU, Human Rights in CONSTitutional LAW 55 (2nd ed. 2005).

10 HAROLD J. LASKI, A GRAMMAR OF POLITICS 97 (1967). 
The Constitution framers did not find state as a necessary evil but rather as a means to an end; welfare of the people being the end and state as a means to that end. Keeping this in mind, they imposed positive obligation on the state to realise certain socioeconomic rights when it is capable of doing so. ${ }^{11}$ This forms a very important feature of the Constitution viz. Directive Principles of State Policy under Part IV of the Constitution which are the directives given to the state under the Constitution for the establishment of a welfare state. ${ }^{12}$ The fundamental rights and directive principles together constitute the conscience of the Constitution. ${ }^{13}$

Thus, the state in addition to obeying the Constitution's negative injunctions not to interfere with certain of the citizens' liberties must fulfill its positive obligation to protect the citizens' rights from the encroachment by society. ${ }^{14}$ Further for the purpose of Part III and Part IV, state is particularly defined in Article 12 of the Constitution of India. Article 12 is the key to Part III of the Constitution and unless an authority can be said to be a 'state' within the meaning of Article 12, none of the provisions of Part III which relate to the 'state' will apply to such authority. ${ }^{15}$ Moreover, for the effective enforcement of fundamental rights, Article 32 is

11 CONSTITUTION OF INDIA art. 37(1) (“The provisions contained in this Part shall not be enforceable by any court, but the principles therein laid down are nevertheless fundamental in the governance of the country and it shall be the duty of the State to apply these principles in making laws.").

12 CONSTITUTION OF INDIA art. 38(1) ("The State shall strive to promote the welfare of the people by securing and protecting as effectively as it may a social order in which justice, social, economic and political, shall inform all the institutions of the national life.").

13 Glanville Austin, Indian COnstitution: Cornerstone of A NATiON 50 (1985).

$14 \mathrm{Id}$. at 51 (noting that the framers appear to have taken the above precautions in view of the experience of the U.S., where it had been held by the Supreme Court in Civil Rights Cases 109 U.S. 3 (1883) that the equal protection clause of the Fourteenth Amendment inserted after the civil war was applicable only against state action).

${ }^{15}$ The University of Madras v. Shanta Bai, A.I.R. 1954 Mad. 67. 
incorporated which is aptly described by Dr. B.R. Ambedkar as the very heart and soul of the Constitution of India. ${ }^{16}$

\section{Role of the State in the Era of Globalisation}

The term 'globalisation' defies a definition. It is a concept having a multitude dimensions. ${ }^{17}$ Although it has varied dimensions, it is the economic dimension which deserves attention here. The key features of economic globalisation are accelerated integration of global economy by multinational corporations, transformations in financial markets like financial flows etc., global competition, global trade, intra industry trade etc. which diminishes state control.18 Economic globalisation ends the system of independent sovereign states leading to erosion, loss and diminution of state. ${ }^{19} \mathrm{It}$ signals supremacy or triumph of the market over nation state and of economics over politics. ${ }^{20}$

16 VII CONSTITUTIONAL ASSEMBLy DEBATES 953 (1948).

17 Jan Nederveen Pieterse, Globalisation And Culture: Global MÉLANGE 66 (2009) ("In social science there are as many conceptualizations of globalisations as there are disciplines. In economics globalisation refers to economic internationalization and the spread of capitalist market relations. In international relations, the focus is on the increasing density of interstate relations and the development of global politics. In sociology, the concern is with increasing worldwide social densities and the emergence of 'world society'. In cultural studies, the focus is on global communications and worldwide standardization, as in CocaColonization and McDonaldization and on the post-colonial culture. In history, the concern is with conceptualizing 'global history'."); see WiLliam TWINING, GLOBALISATION \& LEGAL THEORY 4 (2000).

18 Nilüfer Karacasulu Göksel, Globalisation and the State, DOKUZ EYLUL U. (Feb. 5, 2012), http://sam.gov.tr/wp-content/uploads/2012/02/1.NiluferKaracasuluGoksel.pdf.

19 Id.; see also SuSAN STRANGE, THE EROSION OF THE STATE 365-369 (1996).

20 Id.; see also Dani Rodrik, Has Globalisation Gone Too Far? 39 CALIF. MGMT. REV. 29-40 (1997); R.N. Haas and R.E. Litan, Globalisation and its Discontents: Navigating the Dangers of a Tangled World, 77 FOREIGN AFFAIRS 2-6 (1998). 
When defining economic globalization, Gavin W. Anderson emphasizes the role of neo liberalism as a political phenomenon which stresses the virtues of the free market and the vices of the big government. ${ }^{21}$ The present market approach perceives that the government or the state is less efficient than markets in providing services to the individual. It considers that in a changing international and transnational environment, not only has the state been an agent of its own transformation, but also a major source of development of globalisation itself. ${ }^{22}$ More importantly, this has resulted in attrition of constitutional values and principles. As rightly said by Anderson, economic globalisation is one of the main factors behind the paradigmatic crisis to constitutional rights, and it is mainly due to the change in the role of the state because of the neo liberal tendencies and practices underlying the principles of globalisation, liberalisation and privatisation. ${ }^{23}$

\section{Indian Scenario}

The Constitution of India establishes a socialistic pattern of society. Socialism in India was the brainchild of Jawaharlal Nehru and the socialism which he tried to materialise through the Constitution was a blend of Marxian and Gandhian Socialism which paves the way for a mixed economy. ${ }^{24}$ According to Nehru "political freedom

21 ANDERSON, supra note 7 at 5.

2227 Philip G. CEnRY, The Dynamics of FinANCiAl Globalisation: TeChNOlogy MARKet StRUCtURE AND POlicy ResPONSE 319-342 (1994).

23 See A. Adonis \& T. Hames, The Thatcher And Reagan Revolution (1994); see also ROBERT NOZIK, ANARCHY, STATE AND UTOPIA (1999) (the neo liberalism state took its shape on the New Right philosophy which emerged in a Thatcherite England in the 1970's and Reagan governments in the U.S.A in 1980's. It is the trinity of Friedrich von Hayek, Robert Nozik and Milton Friedman that is most fundamentally associated with this movement. The Neo-liberalists advocate a 'Minimum Role of State' and perceives social justice carried out by the state as inherently unfair).

24 See M.N. Das, The Political Philosophy of JaWAHARlal NeHru 125167 (1961); Venkitesh Ramakrishnan, Neoliberal Plan, FrONTLINE, Dec. 8 2012 at 4 ("Marxism was rooted deeply in Nehru's mind but it appeared to him that it was full of dogmas' and he was against any kind of dogma. 
and independence were no doubt essential, but they were steps only in the right direction; without social freedom and a socialistic structure of society and the state, neither the country nor the individual could develop much" ${ }^{25}$ During those times state was conceived as an institution which stands for the welfare of the people. This concept of statehood has undergone a drastic change ever since the emergence of globalisation. The state is now a 'service facilitator' rather than a 'service provider' ${ }^{26}$

In India, the seeds of globalisation were sown in the early 1980's but the real thrust was provided by the New Economic Policy (1991) of Narasimha Rao government. ${ }^{27}$ The policy is based on a perspective which is fundamentally different from the model of economic development as envisaged by the framers of the Constitution. They had envisioned that basic industries should be owned or controlled by the state and the private sector must accept the national plan. This was in consonance with the mixed economy vision which was deeply rooted in the Constitution. ${ }^{28}$ What was initiated by the Congress in 1991 was subsequently taken over by

That is one of the reason why even while accepting Marxism he didn't blindly followed Marxist views as that of in Russia.").

25 JAWAHARLAL NEHRU, TOWARDS FREEDOM 166 (1941).

26 See Guido Bertucci \& Adriana Alberti, Globalisation and Role of the State: Challenges and Perspectives, UNITED NATIONS (Nov. 2, 2012), availabe at http://unpan1.un.org/intradoc/groups/public/documents/un/ unpan006225.pdf.

27 See ANIL KUMAR JAIN \& PARUL GUPTA, Globalisation: The Indian Experience, MAINSTREAM WEEKLy, Feb. 2008, at 8; C.P. BHAMBHRI, THE INDIAN STATE FIFTY YEARS 210-237 (1997) (“The collapse of East European Foreign systems, emergence of Transnational Corporations as powerful global players and 'Venue Shifting' or change in the role of I.M.F., World Bank in the post World War II phase coupled with inflation, shortfall in foreign exchange, increase in external debt G.D.P. ratio, loss of creditor confidence due to major economic policy failure during 1980's and in the subsequent years, exhaustion of foreign exchange reserves precipitated the crisis of 1991 and finally it led to the New Economic Policy of 1991.").

28 This was one of the key components in the Election Manifesto of the Indian National Congress during the first General Elections of 1952. 
others, and the concept of mixed economy which was envisaged at the time of independence has been diluted. The welfare functions of the state have now fallen into the hands of private sectors and thus the concept of socialism is now in a disintegrated state.

The emerging trend of globalisation tends to bring to India a neo liberal culture and that is quite evident from the economic measures adopted by the government. ${ }^{29}$ The government is removing those bottlenecks which will hinder foreign investment and affect foreign investor confidence and foreign capital flows. ${ }^{30}$ It is apt to quote the words of the noted economist Nitin Desai, "What we have now is infrastructure fantasies like Delhi Mumbai Industrial Corridor which conjuring up with China in a jiffy. There is no clue as to how these grandiose projects are being implemented or what benefit they would bring to people". Failure of the Structural Adjustment Programme and Stabilization Policies has left structural imbalances showing no signs of recovery and has denied right to livelihood to many. There is denial of social justice principles enshrined in Article 14, 15, 16, and 38 of the Constitution relating to equality and distributive justice. Even though private sector uses public money via public financial institutions there is no reservation in private sector. ${ }^{31}$ What we can see today is that vulnerable sections of the society are out of the mainstream of neo liberal development strategy and planning programmes. This fact itself constitutes negation of democracy and principles of social justice enshrined under the Constitution. In a democracy, the state is supposed to pursue policies that benefit the people, who are sovereign and on the basis of whose electoral verdict the government is formed. ${ }^{32}$

29 Venkitesh Ramakrishnan, Long Away from Avadi, FRONTLINE, Oct. 5, 2012 at 29 ("It includes raising diesel prices, capping subsidiary on LPG cylinders, allowing Foreign Direct Investment (FDI) in multi-brand retail, recent proposal for amendments to the Insurance Bill etc.").

30 Chandrasekhar, For the sake of Foreign Investments, FrONTLINE, Oct. 5, 2012 at 16.

31 Gail OMvedt, Reservation in the Private And Corporate SeCtOR 149, 131-156 (Sikhadeo Thorat, Aryama \& Prashant Negi eds., 2005).

32 Prabhat Patnaik, Ways of Neoliberalism, FronTLine, Dec. 15, 2012 at 6. 
Another notable impact of globalisation is the steady erosion of the rights of the labourers to minimum wages and social security provisions leading to labour unrest. Disinvestment in public sector and privatisation undermined the rights of workers since there is no rule to bind them under the constitutional obligations. ${ }^{33}$ Public law of the country is unequipped to deal with these tribulations. ${ }^{34}$ The problem associated with displacement due to the creation of Special Economic Zone and other development projects also deserves attention here. ${ }^{35}$ Privatisation of education is furthermore a testimony to the shifting of welfare responsibility to private actors.

Thus, the changing scenario has posed serious doubts about the application and efficacy of the fundamental rights and the doubt is mainly based on the ground that with the increasing role of private actors and decreasing role of the state, fundamental rights would be violated more by the private enterprises than by the state. ${ }^{36}$ Therefore, there is a need to redefine the concept of state under Article 12 of the Constitution and to further widen the 'doctrine of state action' to claim fundamental rights against private actors.

33 See Shalini Singh, Disinvestment in PSU in Small Doses, THE HINDU, Sep. 12, 2012; T. K. Rajalakshmi, Bearing the Brunt, 30, FrONTLINE, Oct. 5, 2012 ("Hindustan Copper (9.59\%), Oil India (10\%), R.I.T.E.S. (10\%), M.M.T.C. $(9.33 \%)$ and Nalco $(12.15 \%)$ - has recently been approved by the Cabinet for disinvestment with a target revenue mop-up of Rs. 15,000 crore. The Finance Ministry has picked on S.A.I.L. (which has already received Cabinet approval for sale of 10.82 per cent of its equity) and B.H.E.L. (for which approval was deferred) for divestment on priority.").

34 BALCO Employee's Union (Regd.) v. Union of India \& Ors., A.I.R. 2002 S.C. 350 ("There can be no judicial review of the economic policy of the government.").

35 See Sandeep Agarwal v. Union of India, W.P. No. 278 of 2009 ("There is a necessity for reinstatement of the fundamental right to property due to the large scale displacements caused by the creation of SEZ and other development projects. But the Supreme Court dismissed the petition in 2010 without looking into the merits of the case.").

36 V.N. Shukla, CONSTITUTION OF INDIA 29 (10th ed. 2003); see Rajiv Mabeshwaram, Perspective of the Judiciary to Economic Reforms vis-à-vis Rights of the Poor, ALL INDIA REP. J. 71-83 (2012). 


\section{Horizontal Application of Fundamental Rights in India}

The intention of the judiciary, right from the beginning was not to include private parties under the ambit of 'state' because of two reasons firstly, fundamental rights are guaranteed to the citizens as a protection against the arbitrary actions of the state and not against private individual secondly, private action can be taken care of by the ordinary law of the land.

In some of the cases involving violation of fundamental rights by private individual/authority, the court has given relief to the affected party without going into the question whether the violator was the state or not. ${ }^{37}$ The need of the times is that fundamental rights are to be made available against private entities also, otherwise persons aggrieved by actions of large private corporations, will have no place to turn to, thereby defeating the very purpose of fundamental rights as envisaged by the framers of the Constitution. Though the big corporations cannot be differentiated from private individuals, in substance and reality they are akin to the state and they constitute an important segment of the power structure of the society. 38

In India, the Supreme Court has given favorable indications on including private corporations as 'state' in M.C. Mehta v. Union of India. ${ }^{39}$ The court has deliberated on the question whether a private

37 Bandhua Mukti Morcha v. Union of India, A.I.R. 1984 S.C. 802; M.C. Mehta v. Union of India, A.I.R. 1987 S.C. 1086; Bodhisatwa Gautam v. Subra Chakraborty, A.I.R. 1996 S.C. 1992; Ashok v. Union of India, A.I.R. 1997 S.C. 2298; M.C. Mehta v. Kamal Nath, A.I.R. 2000 S.C. 1997.

38 See Arthur Selwyn Miller, The Modern Corporate State: Private GOVERNMENTS AND THE AMERICAN CONSTITUTION (1976) (to Anderson, two developments in particular have resulted in (some) constitution lawyers no longer treating private power as a peripheral issue: the extent to which, as result of the reconfiguration of the state, private actors are now deeply involved in the performance of traditional state function, and the political concern over the exercise of private power, and the extent to which this threatens rights constitutionalism's goals of protecting freedom and autonomy); see also Farazmand, supra note 6.

39 M.C. Mehta v. Union of India, A.I.R. 1987 S.C. 1086 (The question that arose was whether victims of a gas leak from a private chemical and 
entity discharging important public functions can be considered as 'state'. However Bhagwati C.J., left the question unanswered due to insufficiency of time to consider and reflect on the question in depth. ${ }^{40}$ Retorting to the argument that the inclusion of private entities within the definition of Article 12, would strike a death blow to the policy of private enterprise, his Lordship opined that: "It is through creative interpretation and bold innovation that the human rights jurisprudence has been developed in our country to a remarkable extent and this forward march of the human rights movement cannot be allowed to be halted by unfounded apprehensions expressed by status quoists."

However, despite the rhetoric, the case remains important as the court has observed that the American doctrine of state action might be applicable in India, and therefore, all the functions of a body judged as 'state' need not be public. ${ }^{41}$

A notable instance on wider interpretation of state action doctrine was extending the reach of fundamental rights to political parties' in the case of Bharat Kumar K. Palicha and Anr. v. State of Kerala and Ors., ${ }^{42}$ decided by the Kerala High Court. It was argued by the

fertilizer plant could sue for compensation under Article 32 of the Constitution).

${ }^{40}$ It must be noted that the matter was left undecided by the Court in spite of the fact that the activity of producing chemicals and fertilizers is deemed by the State to be an industry of vital public interest, whose public import necessitates that the activity should be ultimately carried out by the State itself. In fact Chemicals and Fertilizers industries are placed in the First Schedule as Items 19 and 18 respectively which according to the objectives of the Policy Resolutions the Industries (Development and Regulation) Act of 1951 and Section 2 of the same to be controlled by the Union in public interest.

${ }^{41}$ Zee Telefilms Ltd. and Anr. v. Union of India and Ors., A.I.R. 2005 S.C. 2677.

42 A.I.R. 1997 Ker. 291 (in this case, two citizens belonging to Kerala Chambers of Commerce filed a writ for a declaration to the effect that the calling for and holding of a Bundh by a political party is unconstitutional and illegal as it deprives other citizens from enjoying their fundamental rights guaranteed under Article 19 (1) (a) and 21 of the Constitution. The petitioners' submitted that the Court in exercise of its jurisdiction under 
respondents, that a challenge on the basis of violation of fundamental rights under Articles 19 and 21 of the Constitution could be raised only against state action and not to prevent a political organisation or a private citizen from allegedly interfering with that right. ${ }^{43}$ Opposing the argument, the court affirmed its jurisdiction to grant a declaratory relief to the petitioners since the case of the petitioners is based on their fundamental rights guaranteed by the Constitution. ${ }^{44}$ Furthermore, it held that the calling for a bandh by any association, organization or political party and the enforcing of that call by it, is illegal and unconstitutional. ${ }^{45}$

Regarding application of Article 14 and 15 of Constitution against private educational institutions in J.P. Unni Krishnan v. State of Andhra Pradesh, ${ }^{46}$ it was held that private educational institutions do not become an instrumentality of the state by virtue of mere recognition and/or affiliation and hence the concept of 'state action' cannot be extended to these colleges so as to subject them to the discipline of Part III of the Constitution as the institution is not in receipt of any aid, partially or wholly from the state. 47

Article 226 of the Constitution has not only the right but the duty to protect the citizen and his fundamental rights and fundamental freedoms guaranteed to him under Articles 19 and 21 of the Constitution).

43 P. D. Shamdasani v. Central Bank of India, A.I.R. 1952 S.C. 59 (was relied on in support wherein it was held that "the language and structure of Article 19 and its setting in Part III of the Constitution clearly show that the article was intended to protect those freedoms against the State action.").

${ }^{44}$ Communist Party of India (Marxist) v. Bharat Kumar and Ors., A.I.R. 1998 S.C. 184 (the Hon'ble Supreme Court upheld this decision).

${ }^{45} \mathrm{Id}$.

46 (1993) 1 S.C.C. 645 (the Supreme Court was asked to examine the correctness of the decision in Mohini Jain v. State of Karnataka, A.I.R. 1992 S.C. 1858 on a petition filed by Private Medical and Engineering Colleges in the states of Andhra Pradesh, Karnataka and Maharashtra and Tamil Nadu).

${ }^{47} \mathrm{Id}$. at 930. 
In the case of Zee Telefilms Ltd. $\mathcal{E}$ Anr. $v$. Union of India $\mathcal{E}$ Ors., ${ }^{48}$ the apex court while reaffirming the test laid down in Pradeep Kumar Biswas Case made it clear that a private registered society could not be treated as state merely because it has state patronage. ${ }^{49}$ It appeared to the court that there is no need to further expand the scope of 'other authorities' in Article 12 since the situation prevailing at the time of Sukhdev Singh Case is not in existence for the time being since the state is today distancing itself from commercial activities and concentrating on governance rather than on business. 50 On the contrary, the minority opinion showed the necessity to further enhance the public functions test propounded by Mathew J. and opined that in times of privatisation and liberalisation wherein most of the governmental functions are being relegated to private bodies, the actions of private bodies would also be amenable to the writ jurisdiction of the court. ${ }^{51}$

The concept of state has undergone drastic change. Today, the state cannot be conceived of as coercive machinery, wielding thunderbolt of authority. Therefore, the courts should be anxious to

48 A.I.R. 2005 S.C. 2677 (in this case the Court was called upon to determine whether $\mathrm{BCCI}$, the principle body regulating the sport of cricket in India, would fall within the definition of Article 12).

49 A.I.R. 2005 S.C. 2677 (it was held that "the pre-requisite for invoking the enforcement of a fundamental right under Article 32 is that the violator of that right should be a State first." Notably, the minority distinguished the test laid down in Pradeep Kumar Biswas Case by observing that the "deep and pervasive State control test" applies only in cases when a body has been created by the State but for different purposes under the Indian Companies Act, 1956 or the Societies Registration Act, 1860).

50 BALCO Employee's Union (Regd.) v. Union of India, (2002) 2 S.C.C. 333 (the Court cited this in order to substantiate its view on the matter).

51 The Minority discussed at length the position existing in other jurisdictions and held BCCI to be a State on the following grounds (i) involvement of public interest in the activities of the Board (ii) Performance of public function by the Board (iii) Inclusion of the term 'entertainment' which is inclusive of sports under state function in terms of Entry 33 List II of Seventh Schedule (iv) Regulation of right to profession under Article 19 (1) (g) on its own rule by the Board. Existence of de facto and de jure monopoly by the state in cricket. 
enlarge the scope of the definition of state so as to subject the state in all its myriad activities, whether through natural persons or through corporate or private entities, to the basic obligation of the fundamental rights. Attempts should be made by the courts to expand the reach and ambit of these authorities, rather than to attenuate their meaning and content. ${ }^{52}$ From the above judicial expositions, it is crystal clear that the judiciary is distancing itself from including non state actors within the purview of Article 12.53

\section{Conclusion}

The state has always been at the centre stage of societal governance. Traditionally, many countries have embarked on the concept of welfare state, a political system with a high degree of responsibility for the welfare of the population. The onset of globalisation has resulted in significant changes in the traditional role of the state. The social and economic changes which are taking place now are towards establishing a neo liberal state in India. ${ }^{54}$ Despite this, the state is still holding most of the political power and it is the business of the state to maintain the conditions without which a free exercise of human faculties is impossible. This is more so because our state is established on well founded principles of social and economic justice, absence of inequality, equal protection of laws etc. In this context judiciary has to permeate constitutional values and constitutional culture in the decision making process. Besides, the state has the obligation to carry out international human rights that obliges the states to respect constitutional rights and has to set out rules that prevent violations of human rights by private actors. It is pertinent to note the words of MacIver in this regard "government alone can protect the people against the stranglehold these giants (transnational corporations), seeking their

52 Maneka Gandhi v. Union of India, A.I.R. 1978 S.C. 597.

53 Zee Telefilms Ltd. \& Anr v. Union Of India \& Ors., A.I.R. 2005 S.C. 72 (Santhosh Kumar J. ruled that in a democracy there is a dividing line between a State enterprise and a non State enterprise, which is distinct and the judiciary should not be an instrument to erase the said dividing line unless, of course, the circumstances of the day require it to do so.").

${ }^{54}$ M.C. Mehta v. Union of India, A.I.R. 1987 S.C. 1086. 
own advantage, can otherwise fasten on consumer and worker and shareholder alike." 55

\section{Suggestions}

1. A purposive approach must be adopted by the court while interpreting Article 12 taking into account facts and circumstances of each case. The gist of Article 12 has to be expanded by 'progressive' judicial thinking, so as to include within its ambit instrumentalities and agencies performing state function or entrusted with state action.

2. A straight jacket formula as is laid down in Ajay Hasia case for the purpose of ascertaining amenability of these bodies under Article 12 will lead to miscarriage of justice. Public functions test must be applied in the cases of violation of fundamental rights by private bodies, which do not fall under Article 12.

3. Amendment to Article 12 of the Constitution must be carried out in lines with the suggestion given by National Commission on the Review of the Working of the Constitution. According to the commission, private non state entities which discharge important quasi governmental or important public functions, which have repercussions on the life and welfare of the community, can be regarded a 'state'. ${ }^{6}$

4. Rational approach towards existing constitutional provisions will help to ensure justice in the changing scenario. For example Article $32(3)^{57}$ in the Constitution

55 R.M. MACIVER, THE Web OF GOVERNMENT 260 (1965).

56 See National Commission to Review the Working of the Constitution, Enlargement of Fundamental Rights, May 11, 2001, available at http://lawmin.nic.in/ncrwc/finalreport/v2b1-3.htm.

57 CONSTITUTION OF INDIA art. 32(3) (empowers Parliament of India to confer on any other court the power to enforce fundamental rights within the local limits of its jurisdiction all or any of the powers exercisable by the Supreme Court). 
must be put to use. District Courts must be given authority to issue writs for enforcement of fundamental rights. This will also help to avoid burdening of cases in the High Court and Supreme Court. 